\title{
Production and Application of Domestic Input Data for Safety Assessment of Disposal
}

\author{
처분안전성평가를 위한 국내고유 입력자료의 확보와 적용
Chung-Kyun PARK'1), Jae-Kwang LEE, Min-Hoon BAIK, Youn-Myoung LEE, Nak-Youl KO and Jong-Tae JEONG \\ Korea Atomic Energy Research Institute, 989-111 Daedeok-Daero, Yuseong-Gu, Daejeon \\ 박정균1), 이재광, 백민훈, 이연명, 고낙열, 정종태 \\ 한국원자력연구원, 대전시 유성구 대덕대로 989번길 111
}

(Received August 09, 2012 / Revised September 14, 2012 / Approved September 15, 2012)

\begin{abstract}
To provide domestic values of input parameters in a safety assessment of radioactive waste disposal under domestic deep underground environments, various kinds of experiments have been carried out under KURT (KAERI Underground Research Tunnel) conditions. The input parameters were classified, and some of them were selected for this study by the criteria of importance. The domestic experimental data under KURT environments were given top priority in the data review process. Foreign data under similar conditions to KURT were also gathered. The collected data were arranged and the statistical calculations were processed. The properties and distribution of the data were explained and compared to foreign values in view of their validity.

The following parameters were analysed: failure time and early time failure rate of a container, solubility of nuclides, porosity and density of the buffer, and distribution coefficients of nuclides in the geomedia, hydraulic conductivity, diffusion depth of nuclides, groundwater flow rate, fracture aperture, length of internal fracture, and width of faulted rock mass in the host rock.
\end{abstract}

Key words : input parameter, safety assessment, solubility, sorption, diffusion, migration

\section{요 약}

국내 심부지질환경조건을 반영한 처분안전성 평가에 필요한 입력자료를 제공하기위해, 그 동안 국내 지하시험시설(KURT)환경조건에서 많은 실험을 수행해 왔다. 안전성평가코드에 사용되는 많은 입력변수 들 중 중요성이 부각되는 입력변수들을 선정하여, 각 변수별로 수집한 자료를 통계처리를 하여 값 분포 특성을 기술하고, 외국자료 값과 비교평가를 통해 값의 타당성을 검토하였다. 다룬 입력변수로서 용기물 성분야에서 용기수명, 초기파손률을, 완충재물성분야에서는 핵종용해도, 완충재의 공극률, 밀도, 확산계 수, 핵종분배계수를, 암반 및 원계영역에서는 수리전도도, 지하수유속, 핵종분배계수, 확산깊이, 암반균 열폭, 주지하수유동통로까지 거리, 핵종이동오염운의 너비 등이다.

중심단어 : 입력변수, 안전성평가, 용해도, 수착, 확산, 이동

1) Corresponding Author. E-mail : ckpark@kaeri.re.kr 


\section{I. 서 론}

국내 심부지하에 방사성폐기물을 처분했을 경우, 안전성 평가를 위해서는 국내심부지질조건을 반영한 각종 자료를 생산해 내야하고, 이 결과물에 대한 물리화학적 해석과 더불 어, 이를 안전성평가 코드에 사용할 수 있는 형태로 가공하 여 활용하도록 해야 한다. 이를 위해 한국원자력연구원에서 는 그동안 많은 실험과 연구를 수행해 자료를 축적하였다. 국내 실험측정 자료는 지하시험시설(KURT) 지화학 환경에 서 측정한 실험 자료를 중심으로 크게 두 부류로 나눌 수 있 다. 첫 부류는 지하매질 및 지하수유동관련 물성이고, 두 번 째 부류는 핵종이동관련 물성이다. 핵종이동관련 실험은 용 해도, 수착분배계수, 확산계수에 집중되어있다[1,2]. 지하매 질 및 지하수 관련 실험은 암반층 및 주지하수유동통로를 중 심으로 원계영역 지질 관련 자료들이다[3]. 현재 입력변수들 에 대해 국내외 자료를 수집해 분포함수 값을 확보하고 있으 며, Goldsim 코드와 연계해 안전성 평가를 수행할 체계를 갖 추었다.

외국의 경우를 살펴보면, 캐나다는 1980년대부터 SYVAC 이라는 안전성평가코드를 개발하고, 주요 입력변수들을 $500 \mathrm{~m}$ 심도 지하처분시험시설(URL)에서 실험을 통해 생산해 내었다. 이 실험자료들과 모델계산으로 데이터 분포에대한 확률밀도함수를 설정한 후, 무작위추출법으로 자료를 추출 해 안전성평가 작업을 수행하였다[4]. 카나다 NWMO에서는 지하암반층에 처분한 중저준위 폐기물 안전성평가를 수행하 였는데, 실험자료에 근거하지만 입력변수 값의 불확실도가 클 때에는 확률분포함수를 주어 값 변화에 영향을 평가하고, 영향이 적은 매개변수들은 보수적인 자료를 선택하여 쉽게 계산하였다[5].

스웨덴 SKB는 1970년대부터 Stripa 및 Aspo HRL 지하시 험시설을 통해 많은 실험자료를 축적하였다. 최근 고준위처 분용 SR-site에 대한 안전성평가를 통해 다양한 자료를 집대 성하였고[6], 많은 나라들이 스웨덴 자료를 주요참고자료로 삼을 정도로 고준위폐기물처분에 선구적인 연구를 계속 수 행하고 있다. 대부분의 매개변수들의 값을 구한 방법이 한국 과 대동소이하나, 스웨덴 모델에서는 용해도 값을 직접 구 하지 않고, 화학종계산을 통해 정밀한 용해도 값을 구하는 방안을 택하였는데, 이는 핵종용해도가 안전성평가에 미치 는 영향이 상대적으로 크기 때문으로 여겨진다.

미국 SWRi는 처분용기의 방벽기능을 중시해 다양한 재질 에 처분용기를 설정하고 용기물성부분에 세부평가모델을 도
입해 각 재질별 처분시점 시간별 변화를 고려하였다. 나머지 입력자료들에 대해서는 스웨덴 실험자료를 주로 활용하고, 불확실성이 큰 변수들은 최소, 최대 값의 범위를 정하고 그 구간 내에서 동일한 확률로 존재한다고 가정해 사용하였다 [7]. 그밖에도 Yacca Mt. project를 통해 많은 자료를 가지고 있으나, 불포화대수층에 처분하는 개념으로 처분용기주변에 완충재 등을 사용하지 않는 등으로 우리나라와는 처분개념 및 지질조건에 많이 다르다[8].

일본JAEA는 2000년도에 일본지질조건을 반영한 처분타당 성 및 안전성평가를 수행하여 $\mathrm{H} 12$ 보고서를 작성하였다. 이 보고서에서 사용한 안정평가용 입력자료는 주로 실험실에서 측정한 일본 지질에 대표적인 값을 사용하여 정상상태 시나 리오를 통해 안전성평가를 수행하였다. 불확실도가 큰 입력 변수들의 영향을 파악하기위해, 암반균열분포등 일부 단위 모델에서는 확률밀도함수를 도입하여 변위를 주었으나 확률 론적 안전성평가는 하지 않았다[9]. 대신 값의 변위를 주어 각각의 결정론적인 평가 결과를 비교하여 입력변수 값의 차 이가 주는 효과를 분석하였다. 현재 일본은 미즈나미와 호노 로베에 대규모 지하시험시설을 건설중이며, 향 후 이들 심부 지하시설에서 생산한 실험자료를 바탕으로 입력자료 개선을 도모할 것이다. 이 밖에도, 방사성폐기물처분을 위해 많은 나라들이 지하시험시설을 건설하여 자국의 지하환경조건에 서 각 종 매개변수들의 특성을 실험하고 있다. 스위스는 화 강암층인 Grimsel과 점토층인 Mt.Terri, 핀란드는 Onkalo $\mathrm{URL}$, 프랑스는 점토층인 Bure URL등에서 자료를 생산하고 있다.

국내 처분안전성평가를 위해서 현재 Goldsim 코드를 주로 사용하고 있는데 [17], 여기에서 사용하는 입력변수들은 종류 가 방대하므로, 이 많은 입력변수들 중에서 중요성이 부각되 는 항목들을 선택하여 이 논문에서 분석대상으로 삼았다. 선 택한 매개변수들에 대해 국내 실험측정치를 수집해 통계처 리하고, 외국에서 사용한 값과 비교하여, 합리적인 값을 선 정해 안전성평가에 입력 값으로 사용하고, 기존에 사용한 값 과 다를 경우에는 그 이유와 의미를 설명하는 것이 이 논문 의 목적 및 주요내용이다.

\section{II. 입력변수 선정 및 자료취합 방법론}

\section{가. 입력변수 선정}

방대한 갯수가 되는 입력변수들을 체계적으로 다루기 위 해, 우선, 첫 단계로 안전성평가개념에 입각해 처분시스템을 핵종이동구획별로 다음과 같이 분류하였다. 
- 폐기물 : 핵종재고량(source term), 폐기물구성체(waste matrix)

- 처분용기 : 용기재질, 물성, 수명, 초기 파손

- 처분장 구조물 : 터널, 처분장 규모, 기하학적 구조

- 근계영역(Near field)및 공학방벽 : 콘크리트, 완충재 (bentonite), 뒷채움재 (backfill)

- 원계영역(Far field) : 암석, 토양, 침전물, 암반균열, 주지하수 유동통로(MWCF)

- 생태계(Biosphere) : 강, 바다, 식물, 동물, 우물, 농부 등

위의 각 구획별로 다양한 입력변수들이 있는데, 이 많은 입 력변수들 중 다음과 같은 몇 가지 준거를 가지고 안전성평가 에 영향이 큰 중요한 변수를 선정하였다.

- 불확실도가 높은 매개변수 : 천연방벽은 지하매질 구성도 복잡하고 지화학조건도 일정하지 않을 뿐만 아니라 지하에 위치하기 때문에 직접적으로 관련특성을 파악할 수 없어 높 은 불확실도를 가진다. 연관된 핵종이동관련 변수들도 따라 서 다양한 변화폭을 가진다. 또, 처분용기 수명과 같이 진행과 정이 1000 년 이상 장기간일 경우, 예측에 불확실도가 높다.

- 조건변화가 심한 경우 : 인공방벽에서는 처분용기, 완충재, 뒷채움재 등 구성물 사이에 온도분포나 지화학조건, 구성 물질 등이 시공간적으로 조건변화가 심하다.

- 안전성평가에 미치는 중요도가 큰 매개변수 : 핵종용해도 (solubility), 핵종 수착분배계수, 생태계까지 거리등은 값 의 변화에 따라 최종 피폭선량에 미치는 영향이 크다. 특 히, 핵종에 관해 살펴보면, 지하매질과 상호작용이 없는 음이온, 약수착성 장반감기핵종이 지배적인 주요피폭원 이 되므로 안전성평가에 중요하다.

- 설계인자는 고정 값 사용 : 처분용기나 처분장 구조에 관련된 사항은 설계항목에 해당되어 실제 제작 시에는 최 대한 설계치를 만족하게 제작/건설하므로 변수 변화폭이 작다. 그러므로, 이 번 작업에서는 설계인자는 고정값을 사용할 예정이다. 그렇지만, 최적 설계치 계산 등 다른 용 도를 위해서 처분용기 두께, 충전재 두께 등 입력변수들 에 대해 안전성에 미치는 효과를 검토해야한다.

\section{나. 국내외 자료수집 및 통계처리}

선정한 각 입력변수별로 자료를 수집하였다. 수집 자료는 엑셀문서화일로 정리해 다음 단계 통계처리에 대비하였다. 정리는 각 실험조건 및 대상, 준거 등을 일목요연하게 파악할 수 있도록 분류하였다. 국내 실험측정 자료는 KURT내 지화 학 환경에서 측정한 실험 자료를 중심으로 주로 핵종의 용해
도, 수착분배계수, 확산계수에 집중되어있다 $[1,2]$. 암반층 지 하매질 물성에 관한 자료는 KURT현장실험을 중심으로 수리 전도도, 암반균열폭, 크기, 빈도등을 현장 측정하고, 부족한 부분은 모델 모사평가 및 유사조건 외국자료를 도입하였다 [3]. 지하매질에 대한 핵종의 수착분배계수의 경우에는 이미 데이터베이스를 만들어 놓았으므로 이를 활용하여 통계처리 하였다. 이들 자료의 분포특성을 파악하여 분포함수를 결정 하고, 최소, 최대, 평균값 등을 구하여 통계처리 하였다. 같은 방법으로 외국자료도 최대한 확보하여, 상호비교가 가능하도 록 하였다.

\section{III. 입력인자별 값의 분포 및 활용}

\section{가. 처분용기물성}

Goldsim 코드에서 처분용기의 수명은 용기파손시간 (Failure time of a container) 으로 결정하는데, 용기파손시 간은 장기간에 걸친 주변과 상호작용과정이므로 실험으로 측정하기 힘들고, 용기재질 물성과 부식률에 근거해 대개의 경우 설계치로 설정한다. 이번 평가에서는 용기수명 목표치 를 1000 년으로 설정해 계산하였다. 국내개발 처분용기는 탄 소강을 기반으로 외부에 구리를 $10 \mathrm{~mm}$ 두께로 코팅한 구조인 데, 구리의 부식속도를 $1 \mu \mathrm{m} / \mathrm{yr}$ 로 가정하면 1000년 후에 약 $1 \mathrm{~mm}$ 깊이로 부식된다고 볼 수 있다. 외국의 경우를 살펴보 면, 각 나라별로 처분용기 재질이 다르므로 일률적으로 비교 할 수 없는데, $7 \mathrm{~cm}$ 이상 두께의 구리재질을 쓰는 스웨덴 SKB 에서는 용기파손시간을 최소, 최대, 최빈값으로 각각 $0,10^{5}$, $10^{5}$ 년을 사용하였다[6]. 즉 용기의 기대수명이 $10^{5}$ 년이지만 처분시점부터 일부 용기에 파손이 일어날 수 있다고 설정했 다는 뜻이다. 일본 JAEA는 철재용기를 사용하며, 1000년을 기본 값으로 계산하고, $10^{4}, 10^{5}, 10^{6}$ 년을 추가 비교대상으 로 계산하였다[9]. 미국 SWRI의 경우에는 구리, 탄소강, 티타 늄등 다양한 처분용기의 재질과 이들이 접하는 지화학 환경 조건을 고려하여 상세모델을 설정하였다. 처음 방사성폐기 물을 심부지하처분장에 처분하는 시점에서는 대기와 접촉하 는 관계로 산화환경이 되었다가 터널 폐쇄 후 천천히 환원환 경이 되어간다. 용기의 부식률은 이 지화학 조건에 따라 민 감하게 변하므로 용기재질별로 분포 값을 설정하였는데, 최 종적으로 용기수명은 $10^{5}$ 년을 넘기 어려운 것으로 예측된다 [7]. 이상의 외국자료를 종합해보면, 처분용기수명은 처분시 점부터 파손이 있다고 보고, 처분시점 0 년부터 최대 $10^{5}$ 년을 용기수명으로 잡는데, 이 계산에서 1000년으로 설정한 것은 상대적으로 보수적인 값 설정에 해당한다. 
초기용기파손률(Early time failure rate(\%))은 실제 처분 장 운영시 폐기물반입과 밀봉과정과 밀접한 연관이 있는데, 이에 대한 경험치가 전혀 없으므로 가정을 통한 모델 모사 에 의존하게 된다. 미국 SWRI의 경우에는 처분 후 산화조건 과 이후 변하는 환원조건에서 부식률 변화가 크므로 지화학 조건변화를 이들 기간구분에 척도로 사용하여 다른 함수를 사용하였다. 초기 산화조건에서는 삼각함수를 사용하여 최 소, 최빈, 최대값을 각각 $0.25,0.45,0.5 \%$ 로 설정하였고, 이후 환원조건에서는 기간도 장시간이고 부식률도 적어 단 일함수를 사용해 0.01-0.1 사이 값을 가진다고 계산하였 다[7]. 스웨덴, 캐나다 등에서는 용기부식률 등을 이용하여 좀 더 세부적인 화학반응과정을 포함한 다른 모델방식으로 계산하였다 $[5,6]$. Goldsim계산에서는 $0.1 \%$ 를 사용했는데, 미국SWRI계산과 비교해보면, 초기 산화조건에서는 상대적 으로 확률을 낮게 잡았고 이후 환원조건에서는 크게 설정한 경우에 해당한다. Table 1에 Goldsim 계산에서 사용한 값을 제시하고, 외국자료를 종합해 분포를 최소, 최대, 최빈값으 로 나타내었다. 표를 통해서 국내 계산 설정치가 외국의 값 분포범위 내에 있음을 알 수 있다.

\section{나. 완충재(buffer) 물성관련 변수}

완충재로서 대부분 나라들은 벤토나이트나 모래와 혼합 물을 고려하고 있다. 우리나라는 스웨덴 처분개념을 주로 차용하고 있으므로 완충재도 큰 차이가 없으나 스웨덴은 물 로 포화되었을 때 팽창성이 큰 Na-bentonite 를 사용하고, 우리나라는 상대적으로 팽창성이 적은 국산 Ca-bentonite를 사용하는 점이 다르다. 나라별로 모래 함량에 따라 여러 물 성차이를 보인다. 우리나라는 경주 산 벤토나이트를 대상으 로 실험을 많이 수행하였으며, 제작 시 압축압력에 따라 밀 도, 공극률, 확산계수 등이 유기적으로 연관되어 변한다[2].

벤토나이트 밀도를 살펴보면, 스웨덴 SKB의 실험측정치 를 통계처리하여 최빈, 최소, 최대값으로 나타내면 각각 $1562,1484,1640 \mathrm{~kg} / \mathrm{m}^{3}$ 이 된다[2]. 우리나라 물성치들도 이와 유사한 범위로 제작하여 사용하였기 때문에 거의 비슷 한 분포를 가졌다. 일본JAEA은 상대적인 낮은 밀도인 1100 , $1600 \mathrm{~kg} / \mathrm{m}^{3}$ 두 경우를 상정하여 계산하였다[9]. 카나다 $\mathrm{NWMO}$ 에서는 반대로 벤토나이트를 $1900 \mathrm{~kg} / \mathrm{m}^{3}$ 까지 고압

Table 1. Parametric value and its distribution for disposal canisters in safety assessment.

\begin{tabular}{|c|c|c|c|c|}
\hline \multirow{2}{*}{ Parameter } & \multirow{2}{*}{ KAERI data } & \multicolumn{3}{|c|}{ foreign data } \\
\cline { 3 - 5 } & & $\min$ & peak & $\max$ \\
\hline $\begin{array}{c}\text { Failure time of a disposal } \\
\text { canister (yr) }\end{array}$ & 1000 & 0 & $10^{5}$ & $10^{6}$ \\
\hline Early time failure rate (\%) & 0.1 & 0.01 & 0.1 & 0.5 \\
\hline
\end{tabular}

축하여 사용하였다[5]. Goldsim코드계산에서는 $1600 \mathrm{~kg} / \mathrm{m}^{3}$ 을 사용하였다. 고밀도일수록 완충재 성능이 더 크게 발휘 되어 팽창성과 열전도성이 좋아지기 때문에 향후 상용처분 에서는 고밀도 완충재를 선호할 것으로 예상되나 $1600 \mathrm{~kg} / \mathrm{m}^{3}$ 이상에서는 제작기기상 압축강도의 비선형적 급 속한 증가로 일반적으로 여러 나라에서 고밀도를 사용하지 않고 있다. 밀도가 2.2 이상인 암석들의 기원을 살펴보면 대 부분 지구심부 고온고압 하에서 형성된 것임을 감안할 때, 현재는 $1600 \mathrm{~kg} / \mathrm{m}^{3}$ 근처 값이 최적화한 상태로 여겨진다.

완충재 공극률에 대해서 살펴보면, 밀도와 반비례 관계에 있는데, 삼각함수로 최빈, 최소, 최대 값으로 나타내면 각각 $0.435,0.41,0.46$ 수준이다[2]. 카나다 NWMO에서는 벤토 나이트를 더 강하게 압축하여 최빈, 최소, 최대 값으로 각각 $0.3,0.25,0.35$ 를 사용하였다[5]. Goldsim 코드 계산에서 는 0.41 을 사용하였는데, 앞에서 언급한 바와 같이 $1600 \mathrm{~kg} / \mathrm{m}^{3}$ 수준에 완충재를 선호하게 되면 공극률은 0.41 수준이 된다.

확산계수는 경주산 벤토나이트를 대상으로 내부확산 실 험장치를 만들어 다양한 조건에서 많은 실험을 수행하였다 [2]. 외국에서도 확산실험을 많이 수행하였는데, 스웨덴은 다양한 조건과 핵종으로 방대한 실험을 수행하여 자료의 신 뢰도가 가장 높다. 스웨덴 SKB에서는 핵종별, 산화/환원 조 건별로 확산계수를 구한 후, 이를 다시 음이온, 양이온, 비 극성양이온 세 종류로 나누어 유효확산계수를 삼각분포함 수로 아래 표와 같이 산정하였다[6]. 일본 JAEA에서는 안 전성영향이 큰 핵종은 지하수 지화학 조건에 따라 정확한 확산계수 값을 구하고 나머지는 통틀어 보수적으로 단일 값 을 부여하였다. 고려한 주요핵종은 $\mathrm{Cs}, \mathrm{Se}, \mathrm{Tc}, \mathrm{Np}, \mathrm{U}$ 등이 고, 지하수는 민물(fresh), 산화수(oxidizing), 염류(saline) 의 세 종류로 나누어 확산계수 값을 구하였다[9]. 미국 SWRI에서는 일본과 유사하게 안전성영향이 큰 핵종에 대해 서는 지화학 조건에 따라 변하는 값을 고려해 단일함수로 범위를 설정하였다[7]. 이상의 외국자료들과 국내 실험자 료를 비교해보면, 확산계수 값은 압축밀도에 따른 차이가

Table 2. Diffusion coefficient for swedish bentonite, (unit : $\mathrm{m}^{2} / \mathrm{yr}$ )

\begin{tabular}{|c|c|c|c|}
\hline species & low & upper & peak \\
\hline anion & $1.9 \times 10^{-5}$ & $1.9 \times 10^{-3}$ & $3.5 \times 10^{-4}$ \\
\hline cation & $2.9 \times 10^{-3}$ & $6.6 \times 10^{-3}$ & $4.4 \times 10^{-3}$ \\
\hline
\end{tabular}

Table 3. Parametric value and its distribution for the buffer in modeling of safety assessment.

\begin{tabular}{|c|c|c|c|c|}
\hline Parameter & KAERI data & mean/peak & $\min$ & $\max$ \\
\hline Porosity $(-)$ & 0.41 & 0.435 & 0.41 & 0.46 \\
\hline Diffusion coefficient $\left(\mathrm{m}^{2} / \mathrm{yr}\right)$ & $3.78 \times 10^{-4}$ & $6.4 \times 10^{-4}$ & $2.9 \times 10^{-3}$ & $1.89 \times 10^{-2}$ \\
\hline Density $\left(\mathrm{kg} / \mathrm{m}^{3}\right)$ & 1,600 & 1,562 & 1,100 & 1,900 \\
\hline
\end{tabular}


주요 원인이고 나라별 물질에 따른 차이는 크지 않았다. Goldsim코드에서는 확산계수로 핵종별 차이는 무시하고 $3.8 \times 10^{-2} \mathrm{~m}^{2} / \mathrm{yr}$ 를 썼는데, 이는 국내 실험통계상 최빈 값과 유사하고, 스웨덴의 음이온 데이타와 유사한 값으로, 약간 보수적인 값 사용으로 이해할 수 있다.

\section{다. 천연방벽관련 입력변수}

안전성 평가에 쓰인 암반층 및 원계영역 지질 관련 자료 는 우선 KURT에서 측정된 자료를 이용하였고, 직접적인 측 정이 어려운 자료는 지질 및 지하수 모델링으로 예측하였 다. 지하수유동과 관련한 계산은 FeFLOW코드를 사용하였 고, 암반층내 단열에 관한 계산은 FracMan코드를 사용하였 다. 모델계산으로도 결정하기 어려운 사항은 관련된 외국자 료 값을 이용하였다.

\section{(1) 암반층 관련 매개변수}

약 10 여 년간 KURT 내부 관정 및 외부 관정에서 암반층 에 대한 수리시험을 실시하였고, 그 결과를 이용하여 암반 층에서 수리전도도 분포를 추정하였다[3]. 그렇지만, 추정에 이용된 자료의 수가 적어 참고 문헌의 값을 부분적으로 고 려하였다[10]. 수리전도도는 로그정규분포를 갖는 것으로 고 려하여 통계처리한 다음 결과를 Table 4 에 실었다. 측정한 수리전도도 값이 심도에 따라 크게 차이나지 않기 때문에, $200 \mathrm{~m}, 500 \mathrm{~m}$ 두 심도에 이용된 수리전도도는 같은 분포를 이용하였다. 분포에 따르면, 펑균값이 상용로그값으로 -9.12 $\left(=10^{-9.12}\right)$ 이고, 표준편차가 0.48 이였다. 이를 산술단위로 나 타내면, 평균이 약 $1.0 \times 10^{-9} \mathrm{~m} / \mathrm{s}$ 이다. Goldsim계산에서는 심도에 따른 암반균열밀도 차이와 이에 따른 수리전도도 차 이를 고려해 $200 \mathrm{~m}$ 에서는 $1.0 \times 10^{-8} \mathrm{~m} / \mathrm{s}, 500 \mathrm{~m}$ 에서는 1.0 $\times 10^{-10} \mathrm{~m} / \mathrm{s}$ 를 사용하였다.

외국의 경우를 살펴보면, 카나다 NWMO에서는 지하매질 에 따라 수리전도도를 따로 구별해 계산하였는데, 화강암 의 경우, 최빈값(peak), 최소값, 최대값으로 각각 $1.0 \times 10^{-4}$, $9.7 \times 10^{-14}, 1.0 \times 10^{-4} \mathrm{~m} / \mathrm{s}$ 으로 값이 상당히 넒은 범위에 걸쳐 분포하였다 [5]. 미국 SWRI의 경우에는 최소값, 최대값, 중 간값(median)으로 각각 $1.6 \times 10-7,1.6 \times 10^{-5}, 1.6 \times 10^{-6} \mathrm{~m} / \mathrm{s}$ $(5,500,50 \mathrm{~m} / \mathrm{yr})$ 를 부여하였는데 상대적으로 큰 값으로 볼 수 있다[7]. 일본JAEA는 투수계수(transmissivity)를 계산 하여 $10^{-13} \sim 10^{-7} \mathrm{~m}^{2} / \mathrm{s}$ 범위 값을 설정하였는데, 이를 수리 전도도와의 관계식과 지하수물성 값을 이용해 수리전도도 로 환산해보면 $10^{-12} \sim 10^{-6} \mathrm{~m} / \mathrm{s}$ 범위가 된다[9]. 이들 외국 값들과 비교해보면 Goldsim계산 값은 중간 범주에 해당한 다. 암반균열폭(fracture aperture)은 현장에서 측정된 암반의 수리전도도와 지하수 유동계를 전체적으로 고려하여 안전 성 평가에서 이용하는 단열 암반의 균열폭을 계산하고 그 분포를 추정하였다. 추정된 분포는 암반의 수리전도도 분포 와 자료의 수를 고려하여 로그삼각분포로 추정하였고, 두 심도에서 최빈값(peak), 최소값, 최대값을 Table 4 에 정리 하였다.

외국의 경우를 살펴보면, 스웨 덴 $\mathrm{SKB}$ 에서는 로그정규분 포 함수를 사용하여, 평균(mean, $\mu$ )값과 분산도(variance, $\left.\sigma^{2}\right)$ 를 계산해, $\mu\left(\log _{10} \mathrm{e}_{\mathrm{v}}\right)=-3.83(\mathrm{~m}), \sigma\left(\log _{10} \mathrm{e}_{\mathrm{v}}\right)=0.51$ (m) 인데, 이를 산술단위로 환산해서, 평균은 $1.5 \times 10^{-4} \mathrm{~m}$, 최적값은 $\left(\right.$ best $\mathrm{e}_{\mathrm{v}}$ ) $=0.3 \mathrm{~mm}$ 를 사용하였다[6]. 일본JAEA 도 로그정규함수를 설정하여 평균값과 분산도(variance)로 $\mu \log _{10} \mathrm{e}_{\mathrm{v}}=-4.69(\mathrm{~m}), \sigma \log _{10} \mathrm{e}_{\mathrm{v}}=0.54(\mathrm{~m})$ 를 구했는데, 이를 산술단위로 환산하면, 평균은 $4.3 \times 10^{-5} \mathrm{~m}$, 표준편차는 $8.1 \times 10^{-5} \mathrm{~m}$ 가 된다[9]. 미국 SWRI의 경우에는 로그단일분포 함수를 설정하여 최소값, 최대값으로 $1 \times 10^{-6}, 1 \times 10^{-2} \mathrm{~m}$ 를 부여하였다[7]. 스웨덴은 결정질 화강암, 일본은 화강암과 퇴적암, 미국은 응회암(tuff)로서 한국은 스웨덴과 같이 결 정질 화강암을 우선적으로 고려하고 있는데, 균열폭분포는 스웨덴, 일본과 비슷한 범주에 있다.

암반매질내 확산깊이(diffusion depth)는 암반균열표면에 서 암반내부로 핵종이 확산해 들어가는 깊이로서 Goldsim 코드에서는 균열표면두께(Rock matric skin thickness)로 표현한다. 확산깊이는 암반균열내를 이동해가는 핵종이 암 반매질내로 포획되는 양태를 나타내므로 확산깊이는 핵종 이동에 지하매질내 수착과 더불어 가장 큰 지연효과를 나타 나며, 특히 음이온이나 트리튬 같은 비수착성 핵종의 경우 에는 지하매질과 상호작용이 거의 없으므로 매질내 확산이 결정적인 지연효과를 나타내며, 확산깊이가 중요한 역할을 한다. KURT 화강암으로 측정한 결과를 Fig.1에 나타내었다 [1]. $\mathrm{Eu}$ 와 $\mathrm{Cs}$ 는 약 $5 \mathrm{~cm}$ 침투해 들어갔고, $\mathrm{Co}, \mathrm{Sr}, \mathrm{Th}$ 는 약 $10 \mathrm{~cm}$ 수준, $\mathrm{U}$ 와 $\mathrm{Np}$ 는 약 $8 \mathrm{~cm}$ 수준이였다. 트리튬 (HTO)은 가장 빠르게 침투해 들어갔다. 카나다 AECL에서 지하현장실험시설인 URL에서 2 년간 실험한 결과 음이온인

Table 4. Parameters for the rockmass in the Goldsim code.

\begin{tabular}{|c|c|c|c|c|c|}
\hline \multirow{2}{*}{ Input parameter } & & \multicolumn{2}{|c|}{ depth $200 \mathrm{~m}$} & \multicolumn{2}{c|}{ depth $500 \mathrm{~m}$} \\
\cline { 3 - 6 } & & Data & Goldsim & Data & Goldsim \\
\hline $\begin{array}{c}\text { Hydraulic } \\
\text { conductivity, } \mathrm{m} / \mathrm{s}\end{array}$ & mean & $1.0 \times 10^{-9}$ & $1.0 \times 10^{-8}$ & $1.0 \times 10^{-9}$ & $1.0 \times 10^{-10}$ \\
\cline { 2 - 6 } & deviation & 0.48 & & 0.48 & \\
\hline \multirow{3}{*}{\begin{tabular}{c} 
Fracture aperture, $\mathrm{m}$ \\
\cline { 2 - 6 }
\end{tabular}} & peak & $4.0 \times 10^{-5}$ & $2.0 \times 10^{-5}$ & $1.0 \times 10^{-4}$ & $1.0 \times 10^{-4}$ \\
\cline { 2 - 6 } $\begin{array}{c}\text { Rock matric skin } \\
\text { thickness, } \mathrm{m}\end{array}$ & $1.0 \times 10^{-5}$ & & $1.0 \times 10^{-5}$ & \\
\cline { 2 - 6 } & max. & $4.0 \times 10^{-4}$ & & $1.0 \times 10^{-3}$ & \\
\cline { 2 - 6 } & min. & 0.1 & 0.1 & 0.1 & 0.1 \\
\cline { 2 - 6 } & max. & 1.0 & & 0.03 & \\
\hline
\end{tabular}




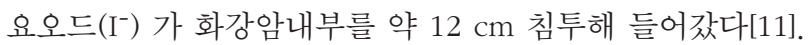
스위스 지하시험시설 (Grmsel)에서 수행한 장기 확산실험 (Long-Term Diffusion project)에서 트리튬은 화강암을 2년 간 약 $18 \mathrm{~cm}$ 를 침투해 들어갔다[16]. 또한, 100년 이상의 장 기실험은 현실적으로 어려우므로 자연유사연구(Natural analogue study)를 통해서 핵종이 수많은 세월동안 암반균 열에서 암석내부로 확산해 들어간 양태를 찾았는데, 주로 지하수에 용해되어 있던 우라늄이 암반내로 확산해 들어가 고 오래기간이 경과하면서 방사능붕괴가 되어 동위원소 간 비율이 달라지는 점을 이용하여 여러 나라에서 확산깊이를 측정하였는데, 이를 정리하면 Table 5와 같다[9]. 이런 장기 확산 실험결과를 종합하여 핵종확산깊이를 최소 $3 \mathrm{~cm}$, 최대 $100 \mathrm{~cm}$, 최빈값 $10 \mathrm{~cm}$ 를 설정하였다.

\section{(2) 원계영역내 주지하수유동통로(MWCF) 관련 자료}

처분장에서 누출될 것으로 예상되는 방사성핵종이 단열 암반을 거쳐 생물권(biosphere)으로 이동하는 주요통로가 될 주지하수유동통로(Major Water Conducting Feature, $\mathrm{MWCF}$ )를 안전성평가모델에 설정하였다. 따라서 $\mathrm{MWCF}$ 를 통과하는 핵종을 모델링하기 위해 필요한 변수들을 제안하 고, 지하수 및 핵종이동 평가를 위해 주요 변수에 대한 값의 분포를 추정하였다. 처분장에서 MWCF에 도달하는 핵종의 이동거리, MWCF 내부에서 지하수 유속, 방사성핵종의 오 염운(plume)이 MWCF를 거쳐 생물권으로 노출될 때의 오

Table 5. Natural analogue for diffusion depth of uranium in rocks.

\begin{tabular}{|c|c|}
\hline Place & diffusion depth of uranium (mm) \\
\hline Boeststein, Swiss & $30-40$ \\
\hline Stripa Mine, Sweden & 25 \\
\hline Kamulunge, Sweden & $30-70$ \\
\hline Palmottu, Finland & 80 \\
\hline El Berrocal, Spain & $35-80$ \\
\hline URL, canada & 50 \\
\hline Kamaishi, Japan & $10-100$ \\
\hline
\end{tabular}

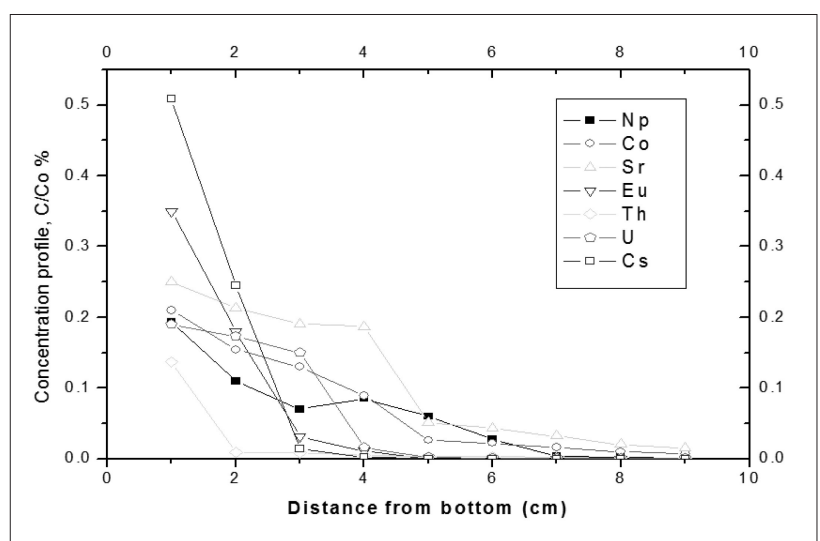

Fig. 1. Diffusion depth of nuclides in weathered granite after 9 months.
염운의 너비 등을 확률분포함수로 설정하였다. 여기서 오염 운의 의미는 구름형태로 이동하는 방사성핵종을 함유한 오 염영향영역을 의미한다. 선택된 변수들은 측정이 매우 어렵 거나 불가능하기 때문에, KURT 지질 자료를 이용한 수리모 델링 결과를 이용하여 분포 추정에 활용하였다. 핵종의 MWCF 도달 거리는 심도별로 계산하였는데, Goldsim계산 시 $200 \mathrm{~m}$ 깊이 심도에서는 짧은 거리인 $100 \mathrm{~m}$ 를 설정하였다. 추후, KURT자료에 근거한 $533 \mathrm{~m}$ 를 사용해 이 거리차이가 안전성에 미치는 영향을 검토해볼 예정이다. MWCF 내에서 단위지하수유속과 오염운의 너비는 두 심도에서 동일한 값 을 갖도록 가정하였다. 일본 JAEA에서 설정한 단위지하수 유속은 $5 \times 10^{-2} \sim 5 \times 10^{1} \mathrm{~m} / \mathrm{y}$ 범위로서 표에 있는 국내 값의 분포보다 더 넓은 범위에 분포하고 있다[9]. 여기서 단위지 하수유속이란 지하수유동량 (discharge rate, $\mathrm{m}^{3} / \mathrm{y}$ )을 단위 면적당 $\left(\mathrm{m}^{2}\right)$ 으로 환산한 값 $(\mathrm{m} / \mathrm{y})$ 이다.

\section{라. 핵종용해도}

KURT내 지화학 조건에서 핵종들의 용해도를 실험을 통 해 측정하여 이를 중심으로 정리하였다. 핵종중에 $\mathrm{Pu}, \mathrm{C}$, $\mathrm{Pa}, \mathrm{Pd}$ 등은 여러 가지 제약조건 때문에 실험하지 못했으며, 이들 자료는 지화학 코드인 PhreeQc를 사용해 계산하였다. 구체적으로 살펴보면, 지화학조건에 따라 용해도가 민감하 게 변하는 핵종들이 있으므로 핵종별로 환원조건, 산화조 건으로 나누어 분포를 정리하여 Table 7에 실었다. 표를 살 펴보면, 대부분 1,2 가 단순 양이온들과 음이온들은 용해도 가 높고 산화/환원조건에 영향을 거의 받지 않았다. 그렇지 만, 악틴족들은 지화학조건에 민감하게 반응하여, 환원조건 에서는 거의 용해되지 않고, 산화조건에서는 상대적으로 용 해되는 현상을 보여준다.

외국의 현황을 살펴보면, 미국 SWRi에서는 주요핵종들에 대해 산화 및 환원조건별로 용해도 함수를 설정하여, 음이온 은 단일함수(uniform), 양이온은 로그단일함수를 설정하여 값 의 분포를 나타내었다[7]. 카나다 AECL에서는 핵종별 산화환 원 조건별로 나누어 정리하였다[4]. 카나다 NWMO 에서는 좀

Table 6. Parameters for MWCF in the Goldsim code.

\begin{tabular}{|c|c|c|c|c|c|}
\hline \multirow{2}{*}{ Input parameter } & & \multicolumn{2}{|c|}{ depth 200m } & \multicolumn{2}{c|}{ depth $500 \mathrm{~m}$} \\
\cline { 2 - 6 } & & Data & Goldsim & Data & Goldsim \\
\hline \multirow{3}{*}{ distance to MWCF, $\mathrm{m}$} & peak & 533 & 100 & 419 & 440 \\
\cline { 2 - 6 } & mean & 430 & & 320 & \\
\cline { 2 - 6 } & deviation & 610 & & 500 & \\
\hline $\begin{array}{c}\text { unit discharge rate } \\
\text { (water velocity) in } \\
\text { MWCF, } \mathrm{m} / \mathrm{yr}\end{array}$ & peak & 13.8 & & 13.8 & \\
\cline { 2 - 6 } & min. & 2.0 & & 2.0 & \\
\cline { 2 - 6 } $\begin{array}{c}\text { width of plume at } \\
\text { the boundary of the } \\
\text { biosphere, } \mathrm{m}\end{array}$ & max. & 25.1 & & 25.1 & \\
\cline { 2 - 6 } & min. & 2,400 & 2500 & 2,400 & 2500 \\
\cline { 2 - 6 } & max. & 4,000 & & 1,600 & \\
\hline
\end{tabular}


더 간단하게 작업하여, 처분안전성평가에 주요핵종으로 나타 난 C, U 는 용해도제한치(solubility limit)를 설정하고, 다른 핵 종들은 잘 용해된다고 보아 보수적 평가를 하였다[5]. 일본은 핵종별로 지하수 지화학 조건에 따라 값을 부여하였다. 지하 수 구성성분과 이온강도에 따라 용해도 차이가 크므로, 지하 수를 민물, 산화수, 염류로 나누고, 처분조건에서 지배적인 화학종과 용해제한 화합물을 고려해 실험치 및 계산치를 적용 하였다 [9]. Sweden SKB는 핵종 용해도를 값으로 제공하지 않 고 지화학 모델을 사용해 각 화학종별 평형상수를 가지고 핵 종의 용해도를 계산하도록 하였다[6]. 이는 핵종 용해도 값의 변화가 안전성평가에 미치는 효과가 크기 때문에 좀 더 정밀 한 값을 사용하기위한 조치로 해석 된다. Table 8은 Goldsim코 드에서 사용한 핵종별 산화/환원 조건별 용해도 값이다. 이를 국내 실험/계산치와 비교해 보면, 이동중 지하매질과 상호작 용이 없어 안전성평가에 미치는 영향이 큰 $\mathrm{Cl}, \mathrm{I}, \mathrm{Se}$ 등 음이온 이나 $\mathrm{Sm}, \mathrm{Cs}, \mathrm{Nb}$ 등 용해도가 큰 핵종들은 보수적인 관점에서 존재하는 모든 양이 용해한다고 설정하였다. 다른 핵종들은 대부분 실험측정값보다 적은 값들을 사용하였는데, 이는 실험 자료분석 결과가 최근에 확보된 탓이며, 안전성평가에 미치 는 영향이 크지는 않지만 차후 측정치 분포를 반영하여 민감 도 분석을 할 필요가 있다. 표에서 -1 은 저농도에서 용해도 제 한이 없음을 나타내기 위해 설정한 기호이다.

\section{마. 핵종의 수착분배계수 $\left(\mathrm{K}_{\mathrm{d}}\right)$}

핵종이 지하수에 용해되어 지하매질을 통해 이동해 가는

Table 7. Solubility data obtained under KURT conditions (unit : $\mathrm{mol} / \mathrm{m}^{3}$ )

\begin{tabular}{|c|c|c|c|c|c|c|}
\hline \multirow{2}{*}{ nuclide } & \multicolumn{3}{|c|}{ Reducing (mol/m3) } & \multicolumn{3}{c|}{ Oxidizing (mol/m33 } \\
\cline { 2 - 7 } & min & peak & $\max$ & min & peak & max \\
\hline $\mathrm{Ac}$ & $2.00 \mathrm{E}-06$ & $1.00 \mathrm{E}-04$ & $5.00 \mathrm{E}-04$ & & $1.00 \mathrm{E}-02$ & \\
\hline $\mathrm{Am}$ & $2.00 \mathrm{E}-06$ & $1.00 \mathrm{E}-04$ & $5.00 \mathrm{E}-04$ & & $1.00 \mathrm{E}-02$ & \\
\hline $\mathrm{C}$ & $1.50 \mathrm{E}-01$ & $1.00 \mathrm{E}+00$ & $4.00 \mathrm{E}+03$ & $1.50 \mathrm{E}-01$ & $1.00 \mathrm{E}+00$ & $4.00 \mathrm{E}+03$ \\
\hline $\mathrm{Cl}$ & $6.00 \mathrm{E}+03$ & $7.00 \mathrm{E}+03$ & $3.00 \mathrm{E}+04$ & $6.00 \mathrm{E}+03$ & $6.70 \mathrm{E}+03$ & $3.00 \mathrm{E}+04$ \\
\hline $\mathrm{Cm}$ & $2.00 \mathrm{E}-06$ & $1.00 \mathrm{E}-04$ & $5.00 \mathrm{E}-04$ & & $1.00 \mathrm{E}-02$ & \\
\hline $\mathrm{Cs}$ & $2.00 \mathrm{E}+03$ & $4.00 \mathrm{E}+03$ & $7.00 \mathrm{E}+03$ & $2.00 \mathrm{E}+03$ & $4.00 \mathrm{E}+03$ & $7.00 \mathrm{E}+03$ \\
\hline I & $2.00 \mathrm{E}+03$ & $4.00 \mathrm{E}+03$ & $1.00 \mathrm{E}+04$ & $7.00 \mathrm{E}+02$ & $7.00 \mathrm{E}+02$ & $7.00 \mathrm{E}+03$ \\
\hline $\mathrm{Nb}$ & $5.00 \mathrm{E}-05$ & $1.00 \mathrm{E}-04$ & $1.00 \mathrm{E}-01$ & 0.1 & 1 & 40 \\
\hline $\mathrm{Ni}$ & $5.00 \mathrm{E}-04$ & $5.00 \mathrm{E}-04$ & $1.00 \mathrm{E}+00$ & & $2.00 \mathrm{E}+01$ & high \\
\hline $\mathrm{Np}$ & $5.00 \mathrm{E}-08$ & $2.00 \mathrm{E}-05$ & $7.00 \mathrm{E}-05$ & $5.00 \mathrm{E}-01$ & $3.00 \mathrm{E}+00$ & \\
\hline $\mathrm{Pa}$ & $1.00 \mathrm{E}-05$ & $5.00 \mathrm{E}-05$ & $4.00 \mathrm{E}-04$ & $5.00 \mathrm{E}-06$ & $5.00 \mathrm{E}-05$ & $1.00 \mathrm{E}-02$ \\
\hline $\mathrm{Pd}$ & $1.00 \mathrm{E}-08$ & $1.00 \mathrm{E}-05$ & $2.00 \mathrm{E}-03$ & & $4.00 \mathrm{E}-03$ & \\
\hline $\mathrm{Pu}$ & $3.00 \mathrm{E}-08$ & $5.00 \mathrm{E}-06$ & $5.00 \mathrm{E}-04$ & $5.00 \mathrm{E}-05$ & $5.00 \mathrm{E}-04$ & $3.00 \mathrm{E}-03$ \\
\hline $\mathrm{Ra}$ & $1.00 \mathrm{E}-07$ & $1.00 \mathrm{E}-03$ & $1.00 \mathrm{E}-03$ & & $1.00 \mathrm{E}-01$ & \\
\hline $\mathrm{Rn}$ & Gas & Gas & Gas & Gas & Gas & Gas \\
\hline $\mathrm{Se}$ & $1.00 \mathrm{E}-06$ & $1.00 \mathrm{E}-04$ & $5.00 \mathrm{E}-03$ & & $4.00 \mathrm{E}+03$ & \\
\hline $\mathrm{Sm}$ & $5.00 \mathrm{E}-06$ & $1.00 \mathrm{E}-04$ & $2.00 \mathrm{E}-04$ & & $2.00 \mathrm{E}-01$ & \\
\hline $\mathrm{Sn}$ & $2.00 \mathrm{E}-05$ & $5.00 \mathrm{E}-04$ & $5.00 \mathrm{E}-03$ & $3.00 \mathrm{E}+03$ & $5.00 \mathrm{E}+03$ & $1.00 \mathrm{E}+04$ \\
\hline $\mathrm{Sr}$ & $5.00 \mathrm{E}-02$ & $1.00 \mathrm{E}+01$ & $5.00 \mathrm{E}+02$ & $5.00 \mathrm{E}-02$ & $1.00 \mathrm{E}+01$ & $5.00 \mathrm{E}+02$ \\
\hline $\mathrm{Tc}$ & $2.00 \mathrm{E}-06$ & $1.00 \mathrm{E}-05$ & $1.00 \mathrm{E}-04$ & $1.00 \mathrm{E}-02$ & $1.00 \mathrm{E}-02$ & $1.00 \mathrm{E}-02$ \\
\hline $\mathrm{Th}$ & $1.00 \mathrm{E}-07$ & $5.00 \mathrm{E}-05$ & $5.00 \mathrm{E}-03$ & $1.00 \mathrm{E}-07$ & $5.00 \mathrm{E}-05$ & $5.00 \mathrm{E}-03$ \\
\hline $\mathrm{U}$ & $1.00 \mathrm{E}-07$ & $1.00 \mathrm{E}-05$ & $3.00 \mathrm{E}-03$ & $5.00 \mathrm{E}-02$ & $5.00 \mathrm{E}-01$ & $5.00 \mathrm{E}+00$ \\
\hline $\mathrm{Zr}$ & $2.00 \mathrm{E}-08$ & $1.00 \mathrm{E}-05$ & $1.00 \mathrm{E}-04$ & & & \\
\hline & & & & & & \\
\hline
\end{tabular}

동안 핵종과 지하매질 간에 여러 가지 상호작용이 일어난 다. 핵종이 지하매질 표면에 포획되어 고정상에 부착된 형 태인 수착(收着, sorption)은 핵종이동 지연효과에 가장 큰 효과를 미치는 현상이다. 이를 정량적으로 나타내기 위해 수착분배계수(distribution coefficient, $\mathrm{K}_{\mathrm{d}}$ )를 사용하는데, 핵종과 지하매질, 지화학 조건에 따라 민감하게 변하기 때 문에 단일 값을 설정하기가 어렵다. 국내에서는 십여 년 간 다양한 핵종과 지하매질에 대해 분배계수를 측정해 왔으며, 국내 데이터가 많이 축적되어 있어 이를 데이터베이스 형태 로 만들어 활용하고 있다[1]. 지하조건이 워낙 다양하기 때 문에 이 모든 경우에 대해 실험하기 어렵고 체계적인 이해 를 도모하기위해 많은 나라들이 수착 데이터베이스를 만들 어 운영하고 있다. 많은 실험자료를 체계적으로 정리했기 때문에 이를 통해 원하는 조건하에 예상결과를 쉽게 찾을 수 있고, 더불어 계산을 통해 예측과 통계처리까지 할 수 있 다. OECD/NEA에서는 NEA-SDB, 일본은JAEA-SDB, 독일은 RES3T- Rossendorf expert system을 만들어 운영하고 있 다. 우리연구원에서도 인터넷상에서 이용가능한 KAERI$\mathrm{SDB}(\mathrm{http}: / / \mathrm{sdb}$.kaeri.re.kr)를 만들어 활용하고 있다. 국내 에서는 국제 핵물질통제등 핵종확보와 사용상 어려움 때문 에 $\mathrm{Pu}, \mathrm{Pa}, \mathrm{Pd}$ 등 일부 핵종과 침전물(sediment)에 대해서 는 실험을 수행하지 못했으며 이들은 외국자료를 활용하였 다. 수착성 핵종은 KAERI 값을 중심으로 분포를 계산하였 고, 화학종이 복잡하지 않은 음이온은 단일 값을 사용하였 다. 분배계수는 지하매질별, 핵종별로 정리한 자료가 방대 하여, 여기서는 일 부 예로 벤토나이트와 암석에대한 결과

Table 8. Solubility data used in Goldsim modeling $\left(\mathrm{mol} / \mathrm{m}^{3}\right)$

\begin{tabular}{|c|c|c|}
\hline Element & Cs_Reducing & Cs_Oxidizing \\
\hline Ac & $3.00 \mathrm{E}-09$ & $3.00 \mathrm{E}-09$ \\
\hline $\mathrm{Am}$ & $2.00 \mathrm{E}-09$ & $2.00 \mathrm{E}-09$ \\
\hline $\mathrm{C}$ & $7.00 \mathrm{E}-05$ & $7.00 \mathrm{E}-05$ \\
\hline $\mathrm{Cl}$ & $-1.00 \mathrm{E}+00$ & $-1.00 \mathrm{E}+00$ \\
\hline $\mathrm{Cm}$ & $2.00 \mathrm{E}-09$ & $2.00 \mathrm{E}-09$ \\
\hline Cs & -1 & -1 \\
\hline I & -1 & -1 \\
\hline $\mathrm{Nb}$ & -1 & -1 \\
\hline $\mathrm{Ni}$ & $2.00 \mathrm{E}-05$ & $2.00 \mathrm{E}-05$ \\
\hline $\mathrm{Np}$ & $5.00 \mathrm{E}-09$ & $5.00 \mathrm{E}-09$ \\
\hline $\mathrm{Pa}$ & $2.00 \mathrm{E}-08$ & $2.00 \mathrm{E}-08$ \\
\hline $\mathrm{Pd}$ & $3.00 \mathrm{E}-07$ & $3.00 \mathrm{E}-07$ \\
\hline $\mathrm{Pu}$ & $1.00 \mathrm{E}-10$ & $1.00 \mathrm{E}-10$ \\
\hline $\mathrm{Ra}$ & $1.00 \mathrm{E}-06$ & $1.00 \mathrm{E}-06$ \\
\hline Rn & $-1.00 \mathrm{E}+00$ & $-1.00 \mathrm{E}+00$ \\
\hline $\mathrm{Se}$ & -1 & -1 \\
\hline $\mathrm{Sm}$ & -1 & -1 \\
\hline Sn & $-1.00 \mathrm{E}+00$ & $-1.00 \mathrm{E}+00$ \\
\hline $\mathrm{Sr}$ & $1.00 \mathrm{E}-04$ & $1.00 \mathrm{E}-04$ \\
\hline Tc & $4.00 \mathrm{E}-08$ & 4.00E-08 \\
\hline Th & $6.00 \mathrm{E}-10$ & $6.00 \mathrm{E}-10$ \\
\hline $\mathrm{U}$ & $1.00 \mathrm{E}-08$ & $1.00 \mathrm{E}-05$ \\
\hline $\mathrm{Zr}$ & $1.00 \mathrm{E}-04$ & $1.00 \mathrm{E}-04$ \\
\hline
\end{tabular}


치만을 Table 9, 10에 실었다.

외국의 경우를 살펴보면, 수착분배계수값 분포로 스웨덴 $\mathrm{SKB}$ 는 완충재, 뒷채움재에 대해서는 삼각함수를 사용하고, 암석에 대해서는 로그정규분포를 사용하였다[6]. 카나다 AECL에서는 암석의 물성이 다양하고 지하수조건도 다양하 기 때문에 분포가 넓어 로그정규분포를 사용하였다[12]. 카 나다 NWMO에서는 콘크리트에서 잠재적 위험성이 높은 C, $\mathrm{Cl}, \mathrm{Ni}, \mathrm{Zr}, \mathrm{Nb}, \mathrm{U}, \mathrm{Np}$ 핵종에 대해서는 측정값을 부여하고 나머지 핵종들은 보수적으로 0 을 부여하여 계산 작업을 좀 더 간단하게 하였다 [5]. 미국 SWRi에서는 주요핵종들에 대

Table 9 Distribution coefficient for the buffer. $\left(\mathrm{m}^{3} / \mathbf{k g}\right)$

\begin{tabular}{|c|c|c|c|c|}
\hline Nuclide & Modeling data & min & peak & max \\
\hline Ac & $3.00 \mathrm{E}-01$ & $2.50 \mathrm{E}-01$ & $5.00 \mathrm{E}+00$ & $1.00 \mathrm{E}+01$ \\
\hline $\mathrm{Am}$ & $3.00 \mathrm{E}-01$ & $2.50 \mathrm{E}-01$ & $5.00 \mathrm{E}+00$ & $1.00 \mathrm{E}+01$ \\
\hline $\mathrm{C}$ & $0.00 \mathrm{E}+00$ & $0.00 \mathrm{E}+00$ & $0.00 \mathrm{E}+00$ & $0.00 \mathrm{E}+00$ \\
\hline $\mathrm{Cl}$ & $0.00 \mathrm{E}+00$ & $0.00 \mathrm{E}+00$ & $0.00 \mathrm{E}+00$ & $0.00 \mathrm{E}+00$ \\
\hline $\mathrm{Cm}$ & $3.00 \mathrm{E}-01$ & $2.50 \mathrm{E}-01$ & $5.00 \mathrm{E}+00$ & $1.00 \mathrm{E}+01$ \\
\hline $\mathrm{Cs}$ & $2.00 \mathrm{E}-01$ & $2.00 \mathrm{E}-03$ & $6.60 \mathrm{E}-01$ & $2.97 \mathrm{E}+00$ \\
\hline I & $0.00 \mathrm{E}+00$ & $0.00 \mathrm{E}+00$ & $7.40 \mathrm{E}-03$ & $5.00 \mathrm{E}-03$ \\
\hline $\mathrm{Nb}$ & $2.00 \mathrm{E}-02$ & $2.00 \mathrm{E}-02$ & $1.00 \mathrm{E}+00$ & $5.00 \mathrm{E}+00$ \\
\hline $\mathrm{Ni}$ & $5.00 \mathrm{E}-02$ & $1.00 \mathrm{E}-02$ & $7.00 \mathrm{E}-01$ & $1.00 \mathrm{E}+00$ \\
\hline $\mathrm{Np}$ & $1.00 \mathrm{E}-01$ & $1.00 \mathrm{E}-01$ & $3.00 \mathrm{E}+00$ & $5.00 \mathrm{E}+00$ \\
\hline $\mathrm{Pa}$ & $5.00 \mathrm{E}-02$ & $2.00 \mathrm{E}-02$ & $1.00 \mathrm{E}+00$ & $5.00 \mathrm{E}+00$ \\
\hline $\mathrm{Pd}$ & $1.00 \mathrm{E}-03$ & $5.00 \mathrm{E}-03$ & $1.00 \mathrm{E}-01$ & $2.00 \mathrm{E}-01$ \\
\hline $\mathrm{Pu}$ & $3.00 \mathrm{E}-01$ & $1.00 \mathrm{E}-01$ & $3.00 \mathrm{E}+00$ & $5.00 \mathrm{E}+00$ \\
\hline $\mathrm{Ra}$ & $1.00 \mathrm{E}-01$ & $1.00 \mathrm{E}-03$ & $1.00 \mathrm{E}-02$ & $2.00 \mathrm{E}-01$ \\
\hline $\mathrm{Rn}$ & $0.00 \mathrm{E}+00$ & $0.00 \mathrm{E}+00$ & $0.00 \mathrm{E}+00$ & $0.00 \mathrm{E}+00$ \\
\hline $\mathrm{Se}$ & $0.00 \mathrm{E}+00$ & $1.00 \mathrm{E}-03$ & $3.00 \mathrm{E}-03$ & $2.00 \mathrm{E}-02$ \\
\hline $\mathrm{Sm}$ & $2.00 \mathrm{E}-01$ & $7.00 \mathrm{E}-03$ & $1.00 \mathrm{E}+00$ & $2.50 \mathrm{E}+00$ \\
\hline $\mathrm{Sn}$ & $1.00 \mathrm{E}-03$ & $1.00 \mathrm{E}-03$ & $3.00 \mathrm{E}+00$ & $5.00 \mathrm{E}+00$ \\
\hline $\mathrm{Sr}$ & $5.00 \mathrm{E}-02$ & $1.00 \mathrm{E}-03$ & $1.20 \mathrm{E}-02$ & $3.00 \mathrm{E}+00$ \\
\hline $\mathrm{Tc}$ & $1.00 \mathrm{E}-02$ & $1.00 \mathrm{E}-02$ & $1.00 \mathrm{E}-01$ & $2.50 \mathrm{E}-01$ \\
\hline $\mathrm{Th}$ & $3.00 \mathrm{E}-01$ & $2.00 \mathrm{E}-03$ & $3.00 \mathrm{E}+00$ & $6.00 \mathrm{E}+00$ \\
\hline $\mathrm{U}$ & $5.00 \mathrm{E}-02$ & $2.50 \mathrm{E}-01$ & $5.00 \mathrm{E}+00$ & $1.00 \mathrm{E}+01$ \\
\hline $\mathrm{Zr}$ & $2.00 \mathrm{E}-01$ & $2.50 \mathrm{E}-01$ & $5.00 \mathrm{E}+00$ & $1.00 \mathrm{E}+01$ \\
\hline
\end{tabular}

Table 10. Distribution coefficient for the rocks. $\left(\mathrm{m}^{3} / \mathbf{k g}\right)$

\begin{tabular}{|c|c|c|c|c|}
\hline Nuclide & Modeling data & $\min$ & peak & $\max$ \\
\hline Ac & $4.00 \mathrm{E}-02$ & $4.06 \mathrm{E}+00$ & $5.00 \mathrm{E}+00$ & $1.52 \mathrm{E}+01$ \\
\hline $\mathrm{Am}$ & 4.00E-02 & $4.06 \mathrm{E}+00$ & $5.00 \mathrm{E}+00$ & $1.52 \mathrm{E}+01$ \\
\hline $\mathrm{C}$ & $1.00 \mathrm{E}-04$ & $0.00 \mathrm{E}+00$ & $0.00 \mathrm{E}+00$ & $0.00 \mathrm{E}+00$ \\
\hline $\mathrm{Cl}$ & $0.00 \mathrm{E}+00$ & $0.00 \mathrm{E}+00$ & $0.00 \mathrm{E}+00$ & $0.00 \mathrm{E}+00$ \\
\hline $\mathrm{Cm}$ & $4.00 \mathrm{E}-02$ & $4.06 \mathrm{E}+00$ & $5.00 \mathrm{E}+00$ & $1.52 \mathrm{E}+01$ \\
\hline $\mathrm{Cs}$ & $5.00 \mathrm{E}-02$ & $5.20 \mathrm{E}-02$ & $5.20 \mathrm{E}-02$ & $7.30 \mathrm{E}-02$ \\
\hline I & $0.00 \mathrm{E}+00$ & $0.00 \mathrm{E}+00$ & $0.00 \mathrm{E}+00$ & $0.00 \mathrm{E}+00$ \\
\hline $\mathrm{Nb}$ & $2.00 \mathrm{E}-02$ & $5.00 \mathrm{E}-01$ & $1.00 \mathrm{E}+00$ & $3.00 \mathrm{E}+00$ \\
\hline $\mathrm{Ni}$ & $1.00 \mathrm{E}-01$ & $1.80 \mathrm{E}-02$ & $1.20 \mathrm{E}-01$ & $5.40 \mathrm{E}-01$ \\
\hline $\mathrm{Np}$ & $2.00 \mathrm{E}-01$ & $1.09 \mathrm{E}-01$ & $1.70 \mathrm{E}-01$ & $2.56 \mathrm{E}-01$ \\
\hline $\mathrm{Pa}$ & $5.00 \mathrm{E}-02$ & $1.00 \mathrm{E}-02$ & $1.00 \mathrm{E}-01$ & $1.00 \mathrm{E}+01$ \\
\hline $\mathrm{Pd}$ & $1.00 \mathrm{E}-03$ & $3.00 \mathrm{E}-02$ & $3.00 \mathrm{E}-02$ & $2.97 \mathrm{E}+00$ \\
\hline $\mathrm{Pu}$ & $5.00 \mathrm{E}-01$ & $1.00 \mathrm{E}-03$ & $4.00 \mathrm{E}-03$ & $1.00 \mathrm{E}-01$ \\
\hline $\mathrm{Ra}$ & $2.00 \mathrm{E}-01$ & $5.00 \mathrm{E}-02$ & $1.00 \mathrm{E}-01$ & $5.00 \mathrm{E}-01$ \\
\hline $\mathrm{Rn}$ & $0.00 \mathrm{E}+00$ & $0.00 \mathrm{E}+00$ & $0.00 \mathrm{E}+00$ & $0.00 \mathrm{E}+00$ \\
\hline Se & $0.00 \mathrm{E}+00$ & $7.10 \mathrm{E}-04$ & $8.30 \mathrm{E}-04$ & $1.26 \mathrm{E}-03$ \\
\hline Sm & $2.00 \mathrm{E}-02$ & $7.48 \mathrm{E}-01$ & $1.00 \mathrm{E}+00$ & $1.51 \mathrm{E}+01$ \\
\hline Sn & $1.00 \mathrm{E}-03$ & $2.10 \mathrm{E}-02$ & $2.00 \mathrm{E}-02$ & $3.37 \mathrm{E}-01$ \\
\hline $\mathrm{Sr}$ & $5.00 \mathrm{E}-03$ & $3.50 \mathrm{E}-03$ & $1.00 \mathrm{E}-02$ & $6.90 \mathrm{E}-02$ \\
\hline Tc & $5.00 \mathrm{E}-02$ & $0.00 \mathrm{E}+00$ & $0.00 \mathrm{E}+00$ & $0.00 \mathrm{E}+00$ \\
\hline Th & $2.00 \mathrm{E}-01$ & $4.00 \mathrm{E}+00$ & $5.00 \mathrm{E}+00$ & $7.40 \mathrm{E}+00$ \\
\hline $\mathrm{U}$ & $1.00 \mathrm{E}-01$ & $4.06 \mathrm{E}+00$ & $5.00 \mathrm{E}+00$ & $1.52 \mathrm{E}+01$ \\
\hline $\mathrm{Zr}$ & $2.00 \mathrm{E}-01$ & $4.06 \mathrm{E}+00$ & $5.00 \mathrm{E}+00$ & $1.52 \mathrm{E}+01$ \\
\hline
\end{tabular}

해 지하매질별 산화 및 환원조건별로 로그단일(loguniform)함수를 설정하고 음이온은 단일값(discrete)을 사 용하였다 [7]. 일본 JAEA는 핵종별로 지하수와 지화학 조건 에 따라 실험으로 값을 측정하고 값을 부여하였는데, 지하 수는 민물, 산화수, 염류로 나누고, 처분조건에서 지배적인 화학종과 용해제한 화합물을 고려해 실험치 및 계산치를 적 용하였다 [9].

나라별 특징을 정리해보면, 각 나라별로 처한 심부지하환 경특성을 파악하여, 주요한 지하매질과 지하수, 지화학조건 들을 결정한 다음, 실험을 통해 데이터를 구하고 값분포특 성에 따라 다양한 분포함수를 설정하였다. 현 Goldsim모델 에서 사용한 분배계수 데이터는 대부분 보수적인 값들인데, 향후에는 국내심부지질조건을 반영한 실험자료가 확보되었 으므로 이 자료에 근거해 계산을 수행할 예정이다.

\section{바. 생태계관련 변수}

생태계관련 입력자료는 국내 농수산/ 환경/보건 자료, 스 웨덴 SKB보고서와 일본의 $\mathrm{H} 12$ 보고서 자료를 주로 활용하 였다 $[6,9,14]$. 생태계에 관련 데이터는 이번 작업에서 새로 이 국내 데이터를 취합해 계산하는 과정을 거치지 않았고, 경주 중저준위 방폐장 안전성평가에 사용한 값들을 기준으 로 활용하였다. 생태계 관련 데이터는 방대하고 앞에서 서 술한 위해도평가측면에서 가장 중요한 변수 항목 군에 들어 가지 않으므로, 구체적인 서술을 지양하고 안전성평가과정 을 이해하는데 필요한 기본적인 생태계 자료의 주요 특성치 에 대해서만 간단하게 서술하고자 한다.

GoldSim모델에서는 생태계에서 나타나는 피폭을 두 가지 로 평가하는데, 먼저 근생태계(Near Biosphere)에서 지하수 를 사용함으로써 생기는 피폭과, 원생태계(Far Biosphere) 로 지질계와 생태계간 접점(GBI, Geosphere-Biosphere Interface)에서 핵종누출로 생기는 피폭이다. 근생태계에서 는 피폭집단으로 농부만을 설정하였고, 원생태계에서는 농 부, 민물 및 바다어부 집단을 설정하였다. 피폭경로로는 방 사성핵종으로 오염된 물, 토양, 공기 등에 의한 피폭, 오염 된 동식물 섭취, 자연환경에서 호흡으로 인한 흡입 등을 고 려하였다. 계산에 사용한 값들을 Table 11 과 12에 실었다.

지하수 사용으로 인한 피폭계산에서는 오염영향지역을 지하수 토출량을 관개용수률로 나누어 계산하였다. 지하수 양수로 인한 오염영향권의 크기를 계산하기위해 공기, 표면 토양층, 불포화층(vadose)의 두께를 상정하였다. 토양층과 불포화층의 침식률, 토양의 비중, 함수량, 침투률 등은 국내 지하수문 통계자료를 활용하였다[3, 14]. 
Table 11. Environmental parameters for modeling of Near Biosphere.

\begin{tabular}{|c|c|c|c|c|c|}
\hline Parameter & Value & Parameter & Value & Parameter & Value \\
\hline $\begin{array}{c}\text { Pumped } \\
\text { water }\end{array}$ & $44,550 \mathrm{~m} 3 / \mathrm{yr}$ & $\begin{array}{c}\text { Irrigation } \\
\text { rate }\end{array}$ & $0.75 \mathrm{~m} / \mathrm{yr}$ & $\begin{array}{c}\text { Thickness } \\
\text { of air }\end{array}$ & $1.0 \mathrm{~m}$ \\
\hline $\begin{array}{c}\text { Thickness of } \\
\text { surface soil }\end{array}$ & $0.3 \mathrm{~m}$ & $\begin{array}{c}\text { Thickness of } \\
\text { vadose zone }\end{array}$ & $2.0 \mathrm{~m}$ & $\begin{array}{c}\text { Erosion rate } \\
\text { of soil }\end{array}$ & 0.0001 \\
\hline $\begin{array}{c}\text { Erosion rate } \\
\text { of vadose } \\
\text { zone }\end{array}$ & 0.0001 & $\begin{array}{c}\text { Bulk density } \\
\text { of soil }\end{array}$ & $1,325 \mathrm{~kg} / \mathrm{m}^{3}$ & $\begin{array}{c}\text { Water } \\
\text { content }\end{array}$ & 0.30 \\
\hline $\begin{array}{c}\text { Infiltration } \\
\text { rate }\end{array}$ & $0.70 \mathrm{~m} / \mathrm{yr}$ & $\begin{array}{c}\text { Occupancy } \\
\text { of surface } \\
\text { soil }\end{array}$ & $1,300 \mathrm{hr} / \mathrm{yr}$ & $\begin{array}{c}\text { Occupancy } \\
\text { of pumped } \\
\text { water }\end{array}$ & $120 \mathrm{hr} / \mathrm{yr}$ \\
\hline $\begin{array}{c}\text { Inhalation } \\
\text { rate of } \\
\text { surface soil }\end{array}$ & $1.8 \mathrm{~m} 3 / \mathrm{hr}$ & & & & \\
\hline
\end{tabular}

Table 12. Parameters for plant products in the farmer exposure group.

\begin{tabular}{|c|c|c|c|c|}
\hline Plant product & $\begin{array}{c}\text { Soil } \\
\text { contamination } \\
\text { ratio }\end{array}$ & $\begin{array}{c}\text { Yield of } \\
\text { edible plant } \\
\left(\mathrm{kg} / \mathrm{m}^{2}\right)\end{array}$ & $\begin{array}{c}\text { Depth of } \\
\text { irrigation water } \\
(\mathrm{m} / \mathrm{yr})\end{array}$ & $\begin{array}{c}\text { Fraction of } \\
\text { irrigation } \\
\text { water }\end{array}$ \\
\hline Fruits & 0.00015 & 1.4 & 0.7 & 0.50 \\
\hline Grains & 0.00009 & 0.4 & 0.7 & 0.05 \\
\hline Root vegetables & 0.00015 & 2.4 & 0.7 & 0.30 \\
\hline Green Vegetables & 0.00010 & 3.1 & 0.7 & 0.30 \\
\hline Rice & 0.00009 & 0.5 & 1.9 & 0.05 \\
\hline Pasture & 0.00340 & 3.9 & 0.0 & 0.00 \\
\hline
\end{tabular}

오염된 동식물의 방사선세기는 호흡, 섭취, 외부피폭 등 을 계산하는데 중요하다. 통계대상 식용식물로 과일, 곡물 류, 구근류, 채소, 쌀, 목초를 선정하였다. 이들 식물류에 대 한 방사선의 영향은 토양오염율, 식용식물 산출량, 관개수 의 깊이, 관개잔류수 비등을 사용해 계산하였다. 통계대상 동물로는 닭, 젖소, 돼지, 양과 달걀, 우유, 간 등 부산물도 포함하였다. 이들 동물의 방사선 피폭량을 계산하기위해 마 초량, 토양, 물소비량, 흡입률, 방목면적등 에 관한 자료가 필요하다.

각 원소들은 년 간 방사선 피폭량으로 $\mathrm{Bq} / \mathrm{yr}$ 나 $\mathrm{Sv} / \mathrm{yr}$ 을 사 용하였다. 지하수 사용 농부집단의 경우, 외부 토양피폭, 흡 입, 섭취 등에 대한 피폭전환인자(dose conversion factor) 를 사용해 년간 방사선량에서 피폭선량을 계산하였다.

지질생태계접점 $(\mathrm{GBI})$ 에서는 더 많은 피폭집단을 고려하 였다. 바다와 강의 경계지역은, 주지하수유동통로(MWCF) 에서 지하수가 흘러나오는 지점으로, 오염운의 넓이로 계산 하였다. 이 양을 가지고 대수층에서 바다로 흘러가는 양과 강에서 바다로 흘러가는 양을 계산하였다. 홍수률은 국내 기상관측자료를 활용하였고, 강과 바다에 침전율과 침전물 비중도 고려하였다.

농부의 피폭량 계산에서는 농장과 민물 생산품과 관계된 인자들이, 민물어부와 바다어부는 민물과 바다수산물에 크 게 영향받을 것이다. 농장생산품은 지하수 사용 시에 사용 한 동식물 모델을 그대로 도입하였다. 민물에서는 민물고기 와 갑각류를, 바다에서는 바닷고기와 갑각류, 연체동물류를
주요한 산물로 간주하였다. 이들 세 집단의 피폭률은 흡입, 호흡, 외부피폭 등으로 인한 방사선량을 피폭환산인자를 사 용해 계산하였다.

\section{IV. 결 론}

국내지질환경조건을 반영한 처분안전성을 평가하기위해, 그 동안 수행해온 국내 심부지하특성과 지하시험시설 환경 조건에서 실험한 자료를 수집분류하고, 유사한 조건에서 행 한 외국자료와 상호 비교한 결과, 대부분 외국 실험자료 분 포내에 국내 데이터가 존재해 값의 타당성을 입증할 수 있 었다. 나라별로 입력변수 값을 안전성 평가에 반영하는 방 법에 조금씩 차이가 있었는데, 이는 처분용기와 같이 나라 별로 안전성을 보장하기위해 특히 관심을 두고 개발한 시스 템의 경우에는 더 세부적인 평가모델과 데이터를 활용하는 경향이였다. 핵물질사용에 제한이나 비일상 조건으로 실험 자료를 확보하기 어려운 경우에는 모델모사평가를 통해 자 료를 계산했는데, 차후, 이런 자료들에 대한 신뢰도를 높일 수 있는 방안 확보가 필요하다. 선진외국의 경우, $400 \mathrm{~m}$ 수준 깊이로 처분장과 같은 심도의 처분연구시설에서 실제 처분 조건과 유사한 환경에서 실험을 수행해 결과치의 신뢰도가 높으나, 국내에서는 아직 지하시험시설이 이 수준에 도달하 지 못했기 때문에, 이를 극복하기위한 노력도 필요하다.

\section{References}

[1] M.H.Baik, C.K.Park, S.S.Kim, J.K.Lee, and S.Y.Lee, Investigation on nuclide migration behaviors, KAERI/TR-3433/2011 (2011) (in Korean).

[2] J.W.Lee and W.J.Cho, Hydrothermal behaviors and long-term stability of bentonite buffer materials, J. of the Korean Radioactive Waste Society, 52, pp.145 (2007) (in Korean).

[3] K.S.Kim, K.W.Park, K.Y.Kim, and H.J.Choi, Development of advanced Korean reference HLW disposal system - Site Characteristics, KAERI/TR-4265/2011, pp.64 (2011) (in Korean).

[4] T.Rummery and E.Rosinger, Nuclear fuel waste management : the Canadian approach, NUCLEX'81 (1981). 
[5] R.Walke, A.Bath, A. Bond, N.Calder,P. Humphreys, et al. Postclosure safety assessment(VI) : data, NWMO DGR-TR-2009-08 (2009).

[6] SKB, Data report for the safety assessment SRsite, SKB TR-10-52 (2010).

[7] USNRC, Performance assessment : a model for scoping of options and analyzing risk, user guide (2010).

[8] USDOE, Total system performance assessment, DOE/RW-0508 (1998).

[9] JNC, H12: Project to establish the scientific and technical basis for HLW disposal in Japan, Vol.3 (2000).

[10] Freeze, R.A., and Cherry, J.A., Groundwater, Prentice-Hall, U.S.A (1979).

[11] P.Vilks, J.Cramer, M.Jensen, N.Miller, Indiffusion experiment in granite, J. of Cont. Hydrol. 61, pp.191 (2003).

[12] T. Vandergraaf,K.Tickner, T.Melnyk, The selection of sorption data base for the geosphere model, J. of Cont. Hydrol. 13, pp.327 (1993).

[13] Srikanta Mishra, Assigning probability distributions to input parameters of performance assessment models, SKB TR0211 (2002).

[14] Korean Ministry of Health and Welfare, Report on 2002 national nutrition survey by season (2002) (in Korean).

[15] U.Bergstrm, S.Nordlinder, I.Aggeryd, Models for dose assessments: modules for various biosphere types, SKB TR-99-14 (1999).

[16] A.Martin, The long term diffusion project, 10th ISCO meeting GTS phase VI (2012).

[17] Y.M. Lee and Y.S. Hwang, A GoldSim Model for the Safety Assessment of an HLW Repository, Progress in Nuclear Energy, 51, pp.746, (2009). 